\title{
22. TRACE ELEMENT GEOCHEMISTRY AND PETROGENESIS OF BASALTS FROM DEEP SEA DRILLING PROJECT SITES 556-559 AND 561-5641
}

\author{
J. Hertogen, Universiteit Leuven, Fysico-chemische geologie \\ Th. Sachtleben and H.-U. Schmincke, Ruhruniversität Bochum, Mineralogisches Institut \\ and \\ G. A. Jenner, Max-Planck-Institut für Chemie, Mainz ${ }^{2}$
}

\begin{abstract}
Forty-three samples from DSDP Holes 556-559 and 561-564 were analyzed for rare earth elements (REE), Sc, Cr, $\mathrm{Co}, \mathrm{Hf}, \mathrm{Ta}$, and $\mathrm{Th}$ by instrumental neutron activation analysis.

The recovered basalts range from those depleted in light REE (LREE) to those enriched in LREE. The two types of basalts occur together in Holes 558 and 561 . The depleted basalts have remarkably constant $\mathrm{La} / \mathrm{Yb}, \mathrm{La} / \mathrm{Sm}$, and $\mathrm{La} / \mathrm{Ti}$ ratios and apparently derive from a large, homogeneous, mantle source underneath a segment (1200 km long) of the Mid-Atlantic Ridge. The almost twofold variation in the concentrations of incompatible trace elements in the depleted basalts is primarily due to different degrees of batch partial melting.

The variation of highly to moderately incompatible elements in the Leg 82 enriched basalts can be successfully explained in terms of source mixing between depleted mantle sources and alkaline or nephelinitic magmas similar to Azores Islands magmas. However, the correlation of LREE enrichment with distance from the Azores Triple Junction is tenuous at best, and the enriched alkaline component is probably not directly related to the Azores volcanism.
\end{abstract}

\section{INTRODUCTION}

The geochemical studies of mid-ocean ridge basalts (MORB) from different regions in the northern Atlantic Ocean have revealed regionally marked differences in isotopic and trace element composition that are thought to be related to heterogeneities in the mantle source regions. One of these geochemically anomalous regions in the northern Atlantic is the Azores Triple Junction. Various hypotheses about the nature and origin of such anomalies have been developed based on one of two assumptions: either a mantle plume, enriched with large ion lithophile (LIL) elements rising beneath the Azores (White and Schilling, 1978), or the presence of separate magma reservoirs with different chemistries resulting from a complex melting history in the upper mantle (Wood, 1979).

One objective of Leg 82 was to relate regional variations of basalt geochemistry to geodynamic processes in an anomalous segment of the Mid-Atlantic Ridge, the Azores Triple Junction. Glomar Challenger drilled at nine sites southwest of the Azores (Fig. 1) during Leg 82 . The recovered basalts span a wide range in age and trace element composition, varying from 14 to $37 \mathrm{Ma}$ and from samples enriched in LREE to samples depleted in LREE. In this paper we present rare earth element (REE) and other trace element (Sc, $\mathrm{Cr}, \mathrm{Co}, \mathrm{Hf}, \mathrm{Ta}, \mathrm{Th}$ ) data from 43 selected samples. The trace elements have

\footnotetext{
${ }^{1}$ Bougault, H., Cande, S. C., et al., Init. Repts. DSDP, 82; Washington (U.S. Govt. Printing Office).

2 Addresses: (Hertogen) Universiteit Leuven, Fysico-chemische geologie, B-3030 Leuven, Belgium; (Sachtleben and Schmincke) Ruhruniversität Bochum, Mineralogisches Institut, D4630 Bochum, West Germany; (Jenner, present address) Department of Earth Sciences, Memorial University of Newfoundland, St. John's, Newfoundland A1B 3X5, Canada.
}

been determined by instrumental neutron activation analysis (INAA). Two companion papers (Sachtleben et al. and Jenner et al., this volume) deal with the petrology, chemistry (major elements and $\mathrm{Cr}, \mathrm{Ni}, \mathrm{Rb}, \mathrm{Sr}, \mathrm{Y}, \mathrm{Zr}$, $\mathrm{Nb}, \mathrm{Ba}$ ), and $\mathrm{Nd}$ and $\mathrm{Sr}$ isotopic composition of the same samples.

\section{ANALYTICAL TECHNIQUES}

Samples for this study were selected (1) to be representative of the chemical units (magma groups) as defined by the shipboard party and by onshore analyses (Sachtleben et al., this volume), and (2) to be as fresh as possible. These criteria were checked by major element analyses taking into account only samples with low $\mathrm{H}_{2} \mathrm{O}$ and/or $\mathrm{CO}_{2}$ whenever possible. In addition, thin sections were examined for alteration.

Samples were coarsely crushed in an iron mortar and ground in an agate mill to $60 \mu \mathrm{m}$. Aliquots containing $800 \mathrm{mg}$ of sample were irradiated for 7 hours in a thermal neutron flux of about $2 \times 10^{12}$ neutrons $\mathrm{cm}^{-2} \mathrm{sec}^{-1}$ in the Thetis reactor at Gent University, Belgium. The gamma-ray intensities were measured at Leuven University with a large volume $\mathrm{Ge}(\mathrm{Li})$-detector and a hyperpure $\mathrm{Ge}$ "Low Energy Photon Detector" at intervals of 7 and $20-30$ days after irradiation. Concentrations were determined relative to a secondary "in-house" alkali basalt standard, which has been repeatedly calibrated against USGS BCR-1 reference rock. For details of the analytical technique, see Hertogen and Gijbels (1971). Analytical precision for the different elements can be judged from the errors $(2 \times$ standard error of the mean) reported for Sample 564-9-1, 1-4 cm (Table 1). The errors were calculated from counting statistics and the observed dispersion of results from different countings and/or different gamma rays. The precision is generally better than $2 \%$ for $\mathrm{Sc}, \mathrm{Cr}, \mathrm{Co}, \mathrm{Sm}$, and $\mathrm{Eu} ; 6 \%$ for $\mathrm{La}$, $\mathrm{Tb}$, and $\mathrm{Yb}$; and $12 \%$ for $\mathrm{Ce}$ and $\mathrm{Lu}$. The errors for $\mathrm{Nd}$, Ta, and $\mathrm{Th}$ rapidly increase with decreasing concentration and may be as high as $15-20 \%$ for the most LIL-depleted samples.

\section{RESULTS}

The trace element data obtained by INAA are presented in Table 1. Chemical unit assignments listed in Table 1 are taken from Sachtleben et al. (this volume). 
Table 1. Trace element concentrations (ppm) in Leg 82 basalts.

\begin{tabular}{|c|c|c|c|c|c|c|c|c|c|c|c|c|c|c|c|c|}
\hline $\begin{array}{l}\text { Hole-Core-Section } \\
\text { (interval in } \mathrm{cm} \text { ) }\end{array}$ & $\begin{array}{l}\text { Chemical } \\
\text { unit }\end{array}$ & $\mathrm{Sc}$ & $\mathrm{Cr}$ & Co & La & $\mathrm{Ce}$ & $\mathrm{Nd}$ & Sm & $\mathrm{Eu}$ & Gd & $\mathrm{Tb}$ & $\mathrm{Yb}$ & Lu & Hf & $\mathrm{Ta}$ & Th \\
\hline $556-2-1,83-85$ & 1 & 38.8 & 306 & 51.3 & 1.8 & 6.1 & 5.9 & 2.28 & 0.89 & 3.2 & 0.61 & 2.68 & 0.45 & 1.56 & 0.09 & 0.15 \\
\hline $556-2-5,5-7$ & II & 36.0 & 243 & 40.3 & 2.6 & 9.2 & 8.8 & 3.23 & 1.18 & & 0.85 & 3.53 & 0.63 & 2.35 & 0.13 & $\leq 0.15$ \\
\hline $556-3-2,19-21$ & II & 38.8 & 261 & 44.8 & 2.8 & 9.6 & 9.4 & 3.44 & 1.28 & 4.7 & 0.94 & 3.74 & 0.69 & 2.55 & 0.14 & 0.20 \\
\hline $556-6-5,68-70$ & 11 & 37.6 & 275 & 47.1 & 2.4 & 8.3 & 8.1 & 3.02 & 1.12 & 4.0 & 0.80 & 3.25 & 0.57 & 2.14 & 0.11 & 0.22 \\
\hline $556-7-1,85-87$ & III & 38.7 & 364 & 44.6 & 1.5 & 5.0 & 5.2 & 2.09 & 0.88 & 3.1 & 0.57 & 2.44 & 0.42 & 1.42 & 0.07 & $\leq 0.2$ \\
\hline $556-8-2,27-29$ & III & 40.8 & 281 & 43.6 & 1.45 & 4.8 & 5.0 & 1.88 & 0.79 & 2.7 & 0.51 & 2.20 & 0.39 & 1.29 & 0.07 & $\leq 0.15$ \\
\hline $556-12-3,78-80$ & III & 38.4 & 394 & 42.8 & 1.7 & 5.9 & 5.8 & 2.11 & 0.87 & & 0.57 & 2.35 & 0.42 & 1.45 & 0.07 & $\leq 0.15$ \\
\hline $556-16-2,131-133$ & v & 40.6 & 47 & 42.9 & 2.3 & 7.9 & 6.9 & 3.01 & 1.18 & & 0.80 & 3.22 & 0.59 & 2.13 & 0.13 & $\leq 0.4$ \\
\hline $557-1-1,105-108$ & & 33.9 & 33 & 48.9 & 19.4 & 47.1 & 28.6 & 7.13 & 2.42 & 7.8 & 1.29 & 3.5 & 0.62 & 4.96 & 1.95 & 1.81 \\
\hline $558-27-3,69-72$ & 1 & 32.3 & 478 & 48.1 & 5.7 & 14.4 & 9.3 & 2.72 & 1.02 & 3.5 & 0.63 & 2.34 & 0.42 & 1.84 & 0.53 & 0.63 \\
\hline $558-27-3,116-118$ & I & 32.3 & 488 & 50.1 & 5.9 & 14.2 & 9.0 & 2.69 & 1.01 & 3.4 & 0.61 & 2.25 & 0.41 & 1.83 & 0.53 & 0.65 \\
\hline $558-28-3,118-120$ & II & 38.5 & 402 & 40.2 & 2.7 & 8.4 & 7.3 & 2.49 & 0.94 & 3.7 & 0.65 & 2.63 & 0.47 & 1.70 & 0.15 & 0.31 \\
\hline $558-29-1,63-65$ & III & 35.2 & 342 & 44.2 & 9.8 & 22.6 & 13.4 & 3.37 & 1.19 & & 0.72 & 2.45 & 0.42 & 2.19 & 0.96 & 1.12 \\
\hline $558-29-4,83-85$ & III & 33.9 & 321 & 40.3 & 9.4 & 21.3 & 13.2 & 3.28 & 1.15 & 3.7 & 0.64 & 2.35 & 0.41 & 2.10 & 0.90 & 1.00 \\
\hline $558-31-1,79-82$ & III & 34.8 & 335 & 43.5 & 9.7 & 23.0 & 13.2 & 3.36 & 1.21 & & 0.69 & 2.50 & 0.47 & 2.17 & 0.97 & 1.08 \\
\hline $558-32-1,123-125$ & III & 35.6 & 337 & 47.7 & 10.0 & 22.9 & 13.8 & 3.42 & 1.22 & 3.6 & 0.68 & 2.45 & 0.43 & 2.24 & 0.98 & 1.11 \\
\hline $558-33-2,71-73$ & IVA & 35.7 & 370 & 37.9 & 8.9 & 20.2 & 11.6 & 3.07 & 1.12 & 3.7 & 0.64 & 2.15 & 0.43 & 1.97 & 0.86 & 0.97 \\
\hline $558-34-1,30-32$ & IVA & 35.5 & 366 & 44.1 & 8.7 & 20.5 & 12.2 & 3.03 & 1.09 & 3.3 & 0.60 & 2.18 & 0.38 & 1.94 & 0.86 & 0.94 \\
\hline $558-35-3,110-113$ & IVB & 37.3 & 368 & 50.2 & 6.8 & 16.6 & 10.8 & 2.89 & 1.05 & 3.4 & 0.65 & 2.48 & 0.47 & 1.89 & 0.62 & 0.65 \\
\hline $558-35-4,106-108$ & IVB & 36.3 & 362 & 42.8 & 6.6 & 15.8 & 9.9 & 2.79 & 1.01 & & 0.60 & 2.35 & 0.41 & 1.77 & 0.59 & 0.69 \\
\hline $558-38-1,34-36$ & $\mathrm{v}$ & 35.2 & 446 & 49.7 & 4.8 & 11.8 & 7.1 & 2.13 & 0.81 & 2.6 & 0.51 & 2.02 & 0.36 & 1.32 & 0.46 & 0.52 \\
\hline $558-38-2,61-63$ & IVA & 37.1 & 342 & 44.0 & 7.8 & 18.5 & 11.5 & 3.05 & 1.10 & 3.6 & 0.65 & 2.53 & 0.45 & 2.07 & 0.71 & 0.83 \\
\hline $558-40-1,92-94$ & VI & 36.5 & 462 & 50.2 & 5.0 & 11.8 & 6.7 & 2.18 & 0.83 & 2.8 & 0.50 & 2.06 & 0.39 & 1.40 & 0.47 & 0.55 \\
\hline $558-40-2,7-9$ & VI & 36.0 & 500 & 41.5 & 13.5 & 27.6 & 17.8 & 3.69 & 1.33 & & 0.62 & 1.85 & 0.31 & 2.18 & 1.32 & 1.45 \\
\hline $559-1-1,25-29$ & 1 & 39.0 & 271 & 45.4 & 9.2 & 20.5 & 10.8 & 3.45 & 1.26 & & 0.77 & 3.00 & 0.50 & 2.42 & 0.96 & 1.09 \\
\hline $559-1-2,52-56$ & 1 & 37.9 & 260 & 42.5 & 8.5 & 19.7 & 11.8 & 3.36 & 1.20 & & 0.76 & 2.93 & 0.58 & 2.37 & 0.91 & 0.94 \\
\hline $559-8-1,127-129$ & 1 & 39.0 & 265 & 47.4 & 9.4 & 21.5 & 12.3 & 3.56 & 1.28 & 4.5 & 0.81 & 3.06 & 0.59 & 2.52 & 0.99 & 1.07 \\
\hline $561-1-1,33-38$ & 1 & 34.8 & 391 & 50.5 & 12.3 & 25.9 & 13.5 & 3.4 & 1.2 & 3.7 & 0.69 & 2.51 & 0.46 & 2.16 & 1.29 & 1.52 \\
\hline $561-2-1,143-146$ & II & 43.6 & 239 & 47.8 & 2.7 & 9.0 & 8.9 & 3.12 & 1.22 & 4.3 & 0.88 & 3.72 & 0.69 & 2.11 & 0.17 & 0.34 \\
\hline $561-2-2,138-141$ & II & 41.4 & 232 & 66.5 & 2.6 & 8.3 & 8.3 & 2.95 & 1.13 & 4.0 & 0.79 & 3.48 & 0.62 & 2.00 & 0.16 & 0.26 \\
\hline $561-3-2,47-53$ & II & 39.1 & 232 & 42.9 & 2.4 & 7.8 & 7.3 & 2.77 & 1.06 & 3.9 & 0.76 & 3.29 & 0.58 & 1.85 & 0.14 & $\begin{array}{r}0.19 \\
\end{array}$ \\
\hline $562-1-1,110-112$ & 1 & 39.6 & 228 & 44.3 & 2.6 & 9.0 & 9.3 & 3.28 & 1.25 & 4.8 & 0.89 & 3.61 & 0.64 & 2.30 & 0.14 & $\leq 0.15$ \\
\hline $562-4-1,91-93$ & 1 & 39.1 & 228 & 44.4 & 2.7 & 9.3 & 8.1 & 3.29 & 1.23 & 4.5 & 0.87 & 3.58 & 0.66 & 2.33 & 0.17 & 0.20 \\
\hline $562-6-3,120-123$ & 1 & 41.0 & 244 & 48.5 & 3.1 & 10.0 & 9.5 & 3.41 & 1.31 & 5.0 & 0.93 & 3.69 & 0.70 & 2.47 & 0.21 & 0.25 \\
\hline $562-6-4,1-5$ & II & 36.4 & 247 & 42.4 & 2.5 & 6.8 & 6.7 & 2.55 & 0.98 & 3.7 & 0.70 & 2.79 & 0.50 & 1.72 & 0.16 & $\leq 0.2$ \\
\hline $562-8-2,6-9$ & II & 38.5 & 254 & 43.5 & 2.4 & 7.8 & 7.7 & 2.70 & 1.03 & & 0.73 & 3.10 & 0.56 & 1.82 & 0.16 & 0.19 \\
\hline $563-23-1,30-34$ & 1 & 44.7 & 334 & 44.6 & 2.0 & 6.4 & 5.9 & 2.20 & 0.91 & & 0.65 & 2.78 & 0.54 & 1.51 & 0.12 & 0.17 \\
\hline $563-25-1,19-22$ & I & 41.1 & 321 & 45.2 & 1.85 & 5.7 & 5.3 & 2.06 & 0.83 & 3.0 & 0.57 & 2.51 & 0.43 & 1.41 & 0.11 & 0.24 \\
\hline $563-25-2,21-24$ & II & 43.9 & 257 & 52.0 & 3.6 & 11.0 & 9.5 & 3.30 & 1.26 & & 0.88 & 3.74 & 0.70 & 2.34 & 0.25 & 0.29 \\
\hline $564-1-2,21-25$ & I & 43.7 & 333 & 46.3 & 1.9 & 5.6 & 5.6 & 2.14 & 0.89 & 3.1 & 0.61 & 2.64 & 0.48 & 1.47 & 0.11 & 0.21 \\
\hline $564-1-2,38-40$ & II & 42.4 & 259 & & 3.3 & 10.3 & 9.9 & 3.13 & 1.20 & & 0.84 & 3.40 & 0.61 & 2.25 & & $\leq 0.6$ \\
\hline $564-6-4,71-74$ & II & 39.9 & 227 & 50.7 & 3.8 & 10.6 & 8.7 & 3.13 & 1.17 & 4.2 & 0.81 & 3.40 & 0.59 & 2.25 & 0.28 & 0.35 \\
\hline \multirow[t]{2}{*}{$564-9-1,1-4$} & II & 40.0 & 219 & 42.5 & 4.3 & 11.2 & 9.5 & 3.28 & 1.20 & 4.3 & 0.84 & 3.53 & 0.64 & 2.25 & 0.32 & $\begin{array}{r}0.38 \\
+0.07\end{array}$ \\
\hline & & $\pm 0.5^{\mathrm{a}}$ & \pm 5 & \pm 0.8 & \pm 0.2 & \pm 0.7 & \pm 0.8 & \pm 0.06 & \pm 0.03 & \pm 0.4 & \pm 0.03 & \pm 0.15 & \pm 0.07 & \pm 0.08 & \pm 0.02 & \pm 0.07 \\
\hline
\end{tabular}

a 2 times standard error of the mean.

\section{Compatible Trace Elements (Sc, $\mathrm{Cr}, \mathrm{Co}$ )}

$\mathrm{Sc}, \mathrm{Cr}$, and $\mathrm{Co}$ concentrations are within the ranges typical of MORB from the North Atlantic (Bougault et al., 1979; Wood et al., 1979).

$\mathrm{Sc}$ and (to a lesser extent) Co contents are rather constant, which is in keeping with the scarcity of highly fractionated basalts in the Leg 82 holes. Neither systematic hole-to-hole differences nor clear-cut correlations with magma groups have been observed for Sc and Co.

$\mathrm{Cr}$ contents correlate with $\mathrm{MgO}$ values; for more details, see Sachtleben et al. (this volume), who report $\mathrm{Cr}$ data for a larger number of samples.

\section{Incompatible Trace Elements (REE, Hf, Ta, Th)}

$\mathrm{Ta}$ and $\mathrm{Th}$ strongly correlate with $\mathrm{La}$, whereas $\mathrm{Hf}$ correlates with $\mathrm{Sm}$. The following discussion is, therefore, largely restricted to the REE data.

Hole 556. The eight analyzed samples represent four magma groups and are all "normal" LREE-depleted basalts (N-MORBs) (Fig. 1). Absolute REE abundances span a rather large range, but the relative patterns are markedly similar (i.e., virtually constant $\mathrm{La} / \mathrm{Yb}$ ratios; see Fig. 8 for details). Magma Groups II and V have consistently higher $\mathrm{TiO}_{2}$ contents (Fig. 9) and lower Mgnumbers ( $58 \pm 2$ versus approximately $67 \pm 2$; Sachtleben et al., this volume) than Groups I and III. The same dichotomy shows up in the absolute REE abundances (Fig. 1).

Hole 557. Basalts from this site are unique among Leg 82 samples; they are highly fractionated $(\mathrm{Mg}$-value of 44$)$ and rich in $\mathrm{Fe}$ and $\mathrm{Ti}\left(15 \% \mathrm{FeO}_{\text {tot }}, 3.6 \% \mathrm{TiO}_{2}\right)$ (Sachtleben et al., this volume). The single sample analyzed for trace elements $(557-1-1,105-108 \mathrm{~cm})$ is strongly enriched in LREE (Fig. 1), Hf, Ta, and Th.

Basalts of similar major and trace element compositions are known from Hole 407 in the Reykjanes Ridge at $63^{\circ} \mathrm{N}$ (Wood et al., 1979). However, the strongly LREEenriched basalts from Holes 410 and 410A (Mid-Atlantic Ridge, $45^{\circ} \mathrm{N}$ ) have a distinctly different major element chemistry; most are much less fractionated $(\mathrm{Mg}$ values up to 66), and all have lower $\mathrm{TiO}_{2}(1.4-1.5 \%)$ and $\mathrm{FeO}_{\text {tot }}(7-9 \%)$ contents (Wood et al., 1979). The Hole 557 basalts also differ from the Fe-rich and Ti-rich basalts from the Galapagos spreading center, which are typically depleted in LREE (Clague et al., 1981).

Hole 558. The 15 analyzed samples represent 6 magma groups, and all but one (558-28-3, 118-120 cm; Group 


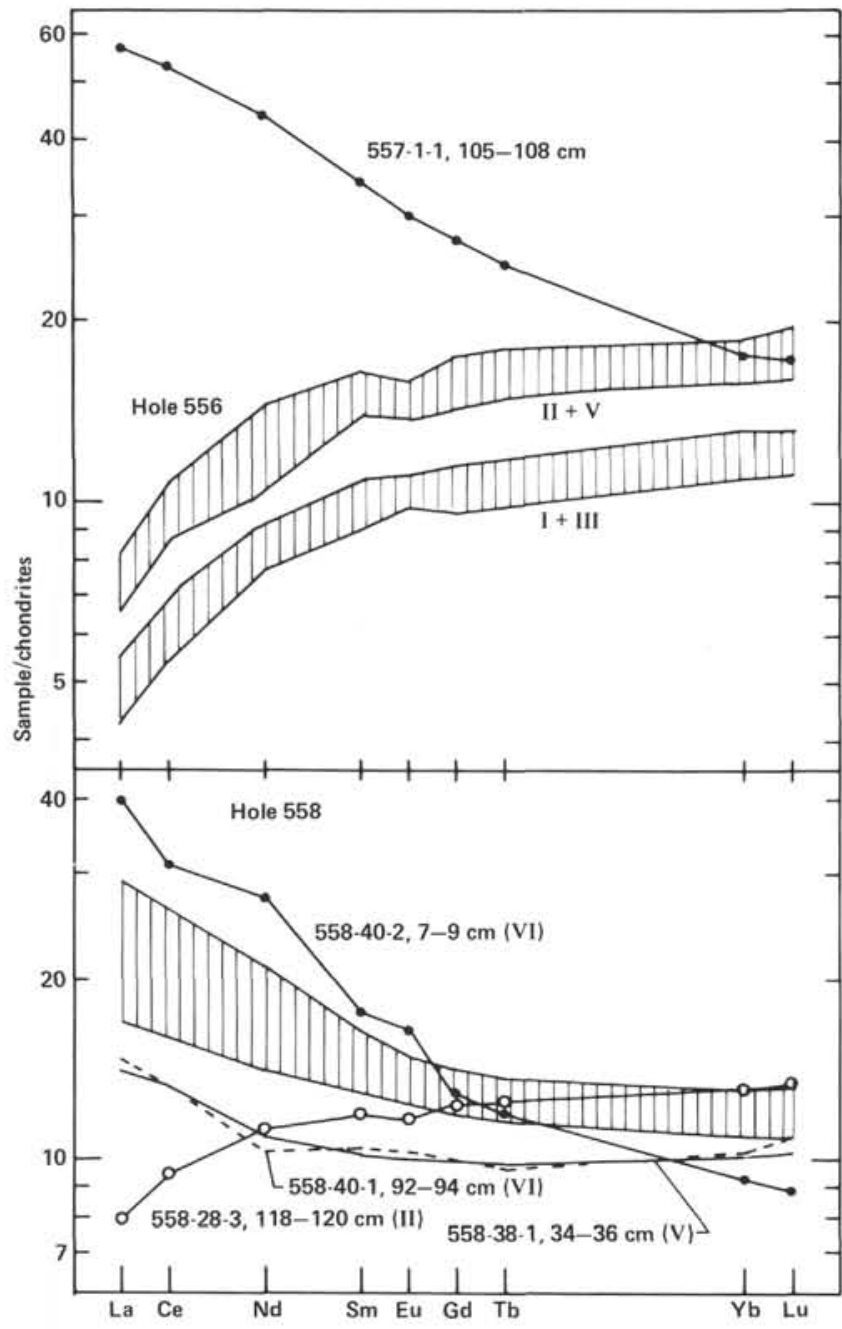

Figure 1. Rare earth element (REE) patterns of basalts normalized to chondrites from Holes 556 (8 samples), 557 ( 1 sample), and 558 (15 samples). Samples from different magma groups (chemical units in Roman numerals) generally have different REE contents. The samples from Hole 558 show the greatest diversity of REE patterns, ranging from LREE-enriched to LREE-depleted. The hatched field for Hole 558 covers the closely spaced patterns of 11 E-MORB samples from Groups I, III, and IV. The irregular REE distribution of Sample 558-40-2, 7-9 cm could be due to alteration.

II) are LREE-enriched basalts (Fig. 1). For the LREEenriched basalts, a correlation between magma group and LREE enrichment is observed: $\mathrm{V}<\mathrm{I}<$ IVA $<$ IVB $<$ III. Group VI is apparently a special case, because the two samples show grossly different REE patterns $(558-40-1,92-94 \mathrm{~cm}$ and 558-40-2, 7-9 cm). The Group VI samples belong lithologically to a breccia unit, but do not seem to form a single chemical unit (Sachtleben et al., this volume). The irregular REE pattern of 558-40-2, 7-9 cm could be due to alteration; the $\mathrm{CO}_{2}$ content $(0.94 \%)$ of this sample is among the highest measured in our sample suite.

The LREE-depleted basalt $(558-28-3,118-120 \mathrm{~cm})$ also has the high $\mathrm{La} / \mathrm{Ta}$ and $\mathrm{Hf} / \mathrm{Ta}$ ratios typical of $\mathrm{N}-\mathrm{MORB}$ (Fig. 5). However, this sample is unusual among the Leg $82 \mathrm{~N}-$ MORBs, because its ${ }^{143} \mathrm{Nd} /{ }^{144} \mathrm{Nd}$ isotopic ratio is virtually indistinguishable from that of the E-MORBs (enriched MORB) from Hole 558 (Jenner et al., this volume).

Hole 559. The basalts from this hole form a single magma group. The three analyzed samples are LREE enriched (Fig. 2) and show only limited variations of trace element abundances.

Hole 561. The two magma groups have distinctly different trace element (Fig. 2) and Nd isotopic (Jenner et al., this volume) characteristics. The occurrence of both E-MORBs and N-MORBs in a single hole underscores the small scale of mantle heterogeneities or the localized nature of mixing processes.

Hole 562. The five analyzed samples are all LREE depleted (Fig. 3). Basalts from magma Group I have consistently higher REE abundances than those from magma Group II.

Hole 563. The two magma groups are LREE depleted but are clearly separated by absolute REE abundances, which are much lower in Group I than in Group II (Fig. 3). Note the similarities between Groups I and II from Holes 563 and 564 .

Hole 564. The sample from magma Group I (564-1-2, $21-25 \mathrm{~cm}$ ) is a typical, depleted N-MORB (Fig. 3). The Group II basalts from Holes 563 and 564, though LREE depleted, have a more transitional character; the $\mathrm{La} / \mathrm{Yb}$ ratios are higher (Fig. 8) and the $\mathrm{Hf} / \mathrm{Ta}$ and $\mathrm{La} / \mathrm{Ta}$ ratios (Fig. 5) are lower than in depleted basalts from the other Leg 82 holes. They are also clearly separated from the

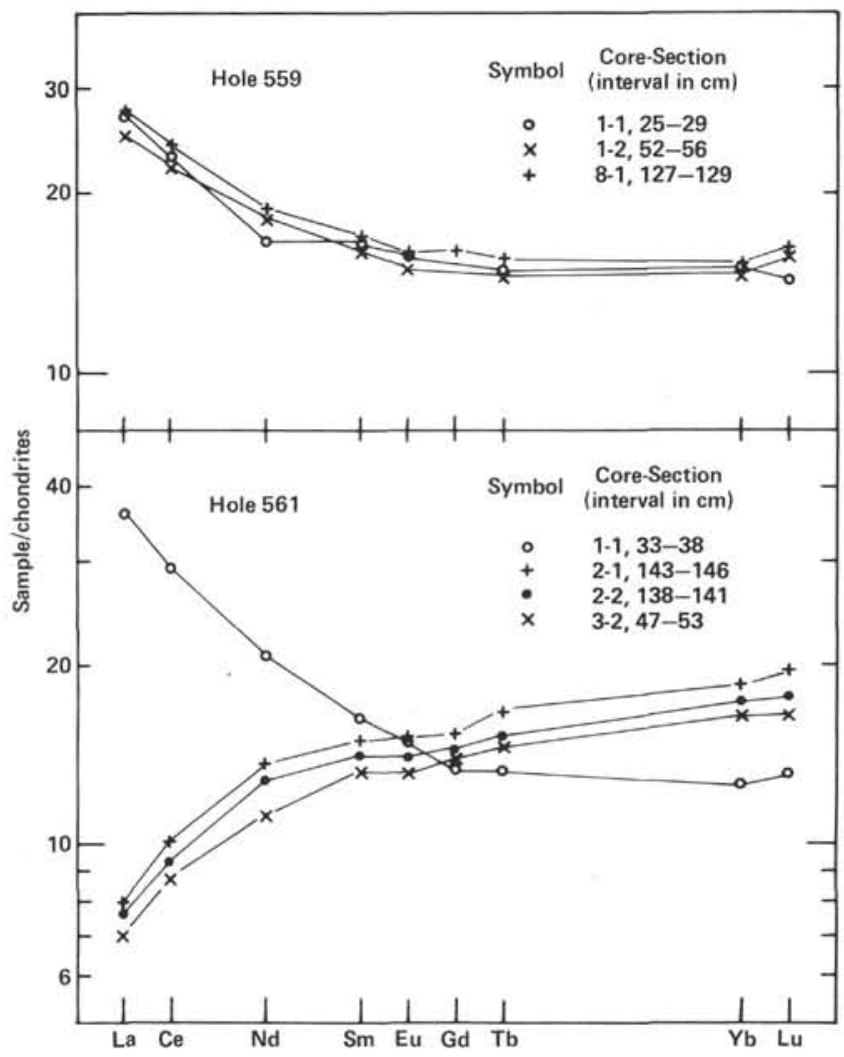

Figure 2. Rare earth element patterns of basalts normalized to chondrites from Holes 559 and 561 . The Hole 559 basalts form a single, very homogeneous, magma group. Enriched (Group I) and depleted (Group II) basalts occur together in Hole 561. 


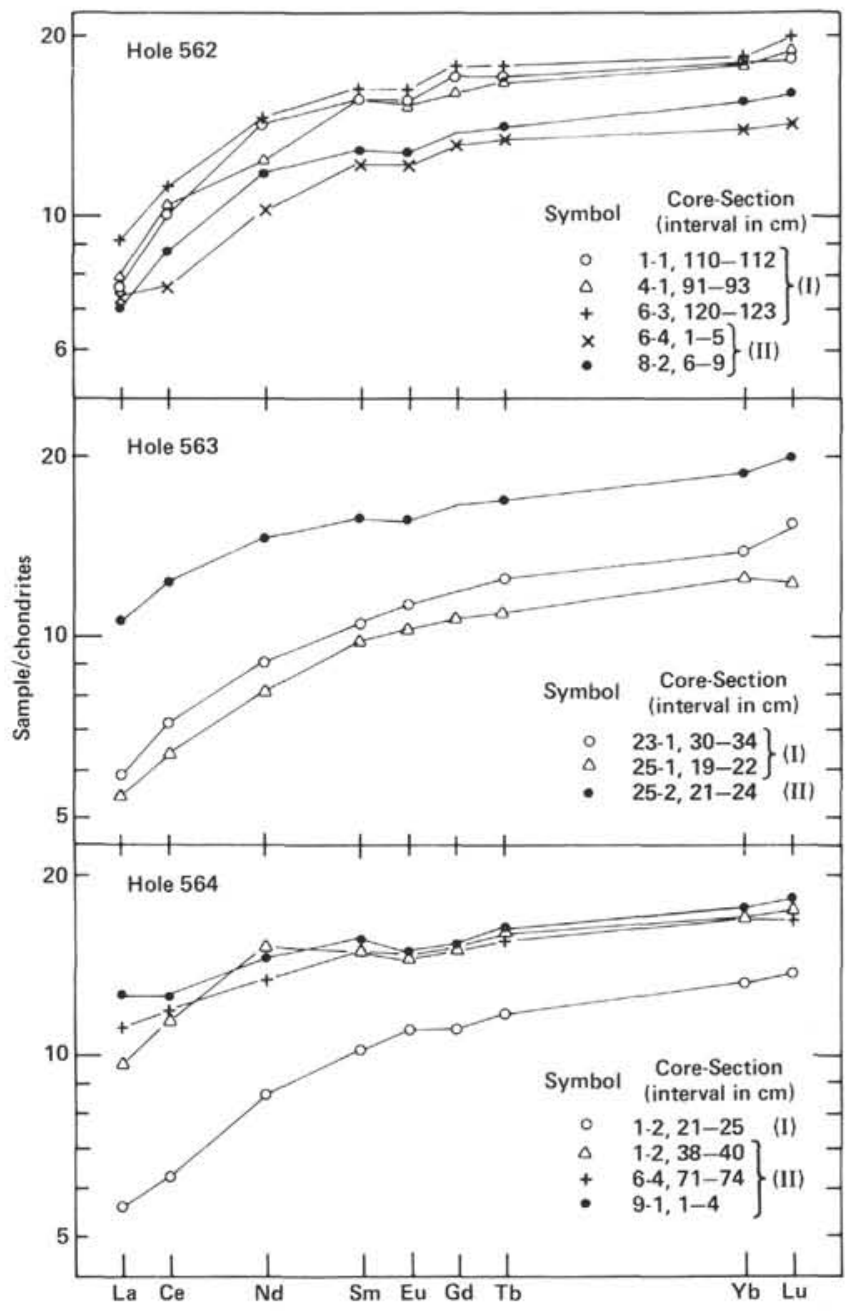

Figure 3. Rare earth element (REE) patterns of basalts normalized to chondrites from Holes 562, 563, and 564. Note the similarity of REE patterns of Group I and II samples from Holes 563 and 564. The Group II basalts from these two holes have somewhat higher $\mathrm{La} / \mathrm{Sm}$ and $\mathrm{La} / \mathrm{Yb}$ (see also Figs. 6 and 8 ) ratios than the LREEdepleted MORBs from the other Leg 82 holes.

common depleted basalts in the $\mathrm{TiO}_{2}$ versus $\mathrm{La}$ variation diagram (Fig. 9).

\section{DISCUSSION}

\section{Trace Element Variations in the Leg 82 N-MORBs}

For the present discussion N-MORBs are defined as those samples that have a $\mathrm{La} / \mathrm{Yb}$ ratio (normalized to chondrites) less than 0.5 and a $\mathrm{La} / \mathrm{Ta}$ ratio greater than 15 (Figs. 5 and 8). The transitional Group II basalts from Holes 563 and 564 (Fig. 3) will be discussed together with the E-MORBs.

The Leg $82 \mathrm{~N}-\mathrm{MORBs}$ have remarkably constant La/ $\mathrm{Yb}, \mathrm{La} / \mathrm{Sm}$, and $\mathrm{La} / \mathrm{Ti}$ ratios, in spite of the almost twofold variation of absolute REE abundances (Figs. 6, $8,9)$. This large variation of REE and other incompatible elements may be due to either substantial (40-50\%) crystal fractionation or different degrees of partial melting. To determine which of these two processes is the most important or the most plausible, we will consider the variation of some critical major and trace elements in the Hole $556 \mathrm{~N}-\mathrm{MORBs}$ that encompass the whole range of chemical variation in the Leg $82 \mathrm{~N}-\mathrm{MORBs}$ (see also Sachtleben et al., this volume). Data for some key elements have been summarized in Table 2 to facilitate the discussion.

The chemical variation within the Hole 556 sequence cannot be explained by high-pressure clinopyroxene fractionation (above 10 kbar; Bender et al., 1978; Fujii and Bougault, 1983). This would lead to a noticeable increase in the $\mathrm{La} / \mathrm{Yb}$ and $\mathrm{La} / \mathrm{Ti}$ ratios and a significant decrease of Sc content with increasing La content. These trends are not observed (Figs. 8 and 9; Table 2). Lowpressure fractionation of olivine alone can also be dismissed because it would rapidly deplete the magmas in $\mathrm{MgO}$ (Fig. 4) and $\mathrm{Ni}$. The depletion in $\mathrm{MgO}$ and $\mathrm{Ni}$ could be largely offset by simultaneous plagioclase crystallization. However, extensive plagioclase fractionation is definitely ruled out by the absence of large negative Eu-anomalies and by the increase of the $\mathrm{Al}_{2} \mathrm{O}_{3} / \mathrm{CaO}$ ratio in the Hole $556 \mathrm{~N}-\mathrm{MORBs}$ (Table 2). Fractionation of plagioclase with $\mathrm{Al}_{2} \mathrm{O}_{3} / \mathrm{CaO}$ around 1.8 -as observed in the cores of phenocrysts-would produce an opposite $\mathrm{Al}_{2} \mathrm{O}_{3} / \mathrm{CaO}$ variation trend. The $\mathrm{Ca} / \mathrm{Al}$ fractionation by plagioclase could in turn be offset by cocrystallization of clinopyroxene. Least-squares mass balance calculations, using high-pressure (7-10 kbar) olivine, clinopyroxene, and plagioclase compositions from Fujii and Bougault (1983), suggest that Sample 556-3-2, 19-21 cm could be related to Sample $556-8-2,27-29 \mathrm{~cm}$ by $21 \%$ clinopyroxene plus $12 \%$ plagioclase fractionation. This result conflicts with the constancy of Sc concentrations and $\mathrm{La} / \mathrm{Yb}$ and $\mathrm{La} / \mathrm{Ti}$ ratios. Moreover, clinopyroxene plus plagioclase without olivine does not appear to be a liquidus phase assemblage within the $1 \mathrm{~atm}$ to $15 \mathrm{kbar}$ pressure range (Bender et al., 1978; Fujii and Bougault, 1983). Therefore, if the major and trace element variation in the Leg $82 \mathrm{~N}-\mathrm{MORBs}$ are to be explained by crystal fractionation, complex mechanisms have to be invoked, such as the fractionation of a continuously replenished magma chamber (O'Hara, 1977). It is, however, beyond the scope of this paper to test the plausibility of this class of models.

Different degrees of batch partial melting of a lherzolite mantle source readily account for the twofold variation of incompatible elements and for the constant $\mathrm{La} /$ $\mathrm{Yb}$ and $\mathrm{La} / \mathrm{Ti}$ ratios of the Leg $82 \mathrm{~N}$-MORBs. A calculated partial melting path has been superimposed on Figure 8 to illustrate this point. The melting model assumed a depleted source consisting of $65 \%$ olivine (OL), $25 \%$ orthopyroxene (OPX), $10 \%$ clinopyroxene (CPX) with $0.26 \mathrm{ppm} \mathrm{La}(0.76 \times$ chondrites $)$, and $0.4 \mathrm{ppm}$ $\mathrm{Yb}(2 \times$ chondrites $)$. The melting proportions were $\mathrm{OL}_{0} \mathrm{OPX}_{0.2} \mathrm{CPX}_{0.8}$ from 0 to $12.5 \%$ melting and $\mathrm{OL}_{0.2} \mathrm{OPX}_{0.8}$ above $12.5 \%$ melting. Crystal/liquid partition coefficients for OL, OPX, and CPX were 0.001 , 0.001 , and 0.03 for $\mathrm{La}$ and $0.001,0.05$, and 0.3 for $\mathrm{Yb}$. The outcome of calculations for a garnet-bearing mantle source is virtually identical provided that the garnet is exhausted from the source at 8 to $10 \%$ melting. The systematic decrease of the $\mathrm{La} / \mathrm{Sr}$ ratio with decreasing 
Table 2. Selected data for Hole 556 samples.

\begin{tabular}{|c|c|c|c|c|c|c|c|c|}
\hline \multirow[b]{2}{*}{$\begin{array}{c}\text { Measured } \\
\text { value }\end{array}$} & \multicolumn{8}{|c|}{ Core-Section (interval in $\mathrm{cm}$ ) } \\
\hline & $\begin{array}{c}8-2 \\
27-29\end{array}$ & $\begin{array}{c}7-1 \\
85-87\end{array}$ & $\begin{array}{c}12-3 \\
78-80\end{array}$ & $\begin{array}{c}2-1 \\
83-85\end{array}$ & $\begin{array}{c}16-2 \\
131-133\end{array}$ & $\begin{array}{c}6-5 \\
68-70\end{array}$ & $\begin{array}{l}2-5 \\
5-7\end{array}$ & $\begin{array}{c}3-2 \\
19-21\end{array}$ \\
\hline $\mathrm{MgO}(\%)$ & 8.09 & 6.74 & 7.99 & 7.80 & 6.57 & 6.94 & 6.18 & 6.10 \\
\hline Mg-number & 68.8 & 64.6 & 67.2 & 67.2 & 56.4 & 61.6 & 56.4 & 57.6 \\
\hline $\mathrm{Al}_{2} \mathrm{O}_{3} / \mathrm{CaO}$ & 1.11 & 1.03 & 1.23 & 1.23 & 1.37 & 1.34 & 1.34 & 1.37 \\
\hline $\mathrm{Ni}(\mathrm{ppm})$ & 136 & 128 & 112 & 121 & 55 & 109 & 79 & 72 \\
\hline Sc (ppm) & 40.8 & 38.7 & 38.4 & 38.8 & 40.6 & 37.6 & 36.0 & 38.8 \\
\hline $\mathrm{La}(\mathrm{ppm})$ & 1.45 & 1.5 & 1.7 & 1.8 & 2.3 & 2.4 & 2.6 & 2.8 \\
\hline $\mathrm{Sr}(\mathrm{ppm})$ & 98 & 106 & 95 & 114 & 120 & 103 & 108 & 108 \\
\hline$(\mathrm{La} / \mathrm{Sr}) \times 10^{4}$ & 148 & 142 & 179 & 158 & 192 & 233 & 241 & 260 \\
\hline
\end{tabular}

Note: From this work and Sachtleben et al. (unpublished data).

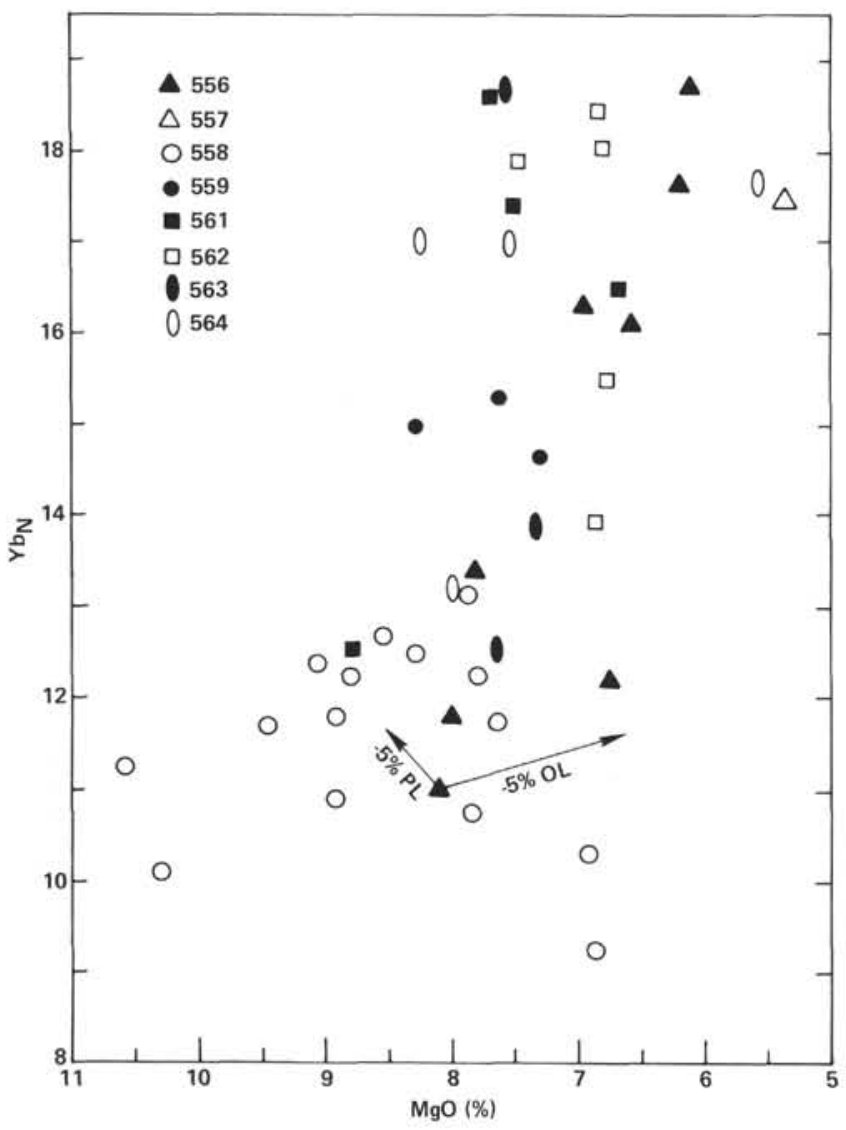

Figure 4. Ytterbium $\left(\mathrm{Yb}_{\mathrm{N}}\right)$ content normalized to chondrites versus $\mathrm{MgO}$ content for Leg 82 basalts. In order to produce the twofold increase of heavy rare earth element (REE) abundances in the N-MORBs (e.g., from Hole 556), low-pressure olivine (OL) + plagioclase (PL) fractionation should be dominated by plagioclase, as shown by the two fractionation vectors. Because extensive plagioclase fractionation is ruled out by the lack of large negative Euanomalies and the variation of the $\mathrm{Al} / \mathrm{Ca}$ ratios, the large variation of REE abundances appears to be the result of different degrees of partial melting (see also Fig. 8).

La content (Table 2) and the small negative Eu-anomalies in some N-MORBs (Figs. 1-3) could imply that plagioclase was a residual source mineral throughout most of the melting range. This would be consistent with the model proposed by Fujii and Bougault (1983).
However, all Leg $82 \mathrm{~N}-\mathrm{MORBs}$ have $\mathrm{MgO}$ contents and Mg-numbers that are too low to qualify the N-MORBs as primary or near-primary mantle melts (Rhodes and Dungan, 1979; Frey et al., 1980). So, even if the twofold variation of incompatible trace elements was primarily established by partial melting, the parental magmas of all N-MORBs most likely went through a stage of olivine fractionation before eruption (Stolper and Walker, 1980). Figure 4 suggests that the N-MORBs could have evolved from a parallel sequence of high-Mg magmas $(\geq 10 \% \mathrm{MgO}$ ) by 5 to $15 \%$ olivine fractionation.

Although the constant $\mathrm{La} / \mathrm{Yb}$ and $\mathrm{La} / \mathrm{Ti}$ ratios of the Leg $82 \mathrm{~N}$-MORBs require a very homogeneous mantle source, the substantial variation of the $\mathrm{La} / \mathrm{Ta}, \mathrm{Hf} / \mathrm{Ta}$, and $\mathrm{La} / \mathrm{Hf}$ ratios (Fig. 5) nevertheless suggests some source heterogeneity or mixing. Indeed, it is generally assumed that basalts inherit the $\mathrm{Hf} / \mathrm{Ta}$ and $\mathrm{La} / \mathrm{Ta}$ ratios of their source region, because these incompatible elements are not substantially fractionated from each other by partial melting and fractional crystallization (Bougault et al., 1979; Wood et al., 1979; Langmuir et al., 1978).

The linear array of the Leg $82 \mathrm{~N}$-MORBs in the Hf/ Ta versus $\mathrm{La} / \mathrm{Ta}$ diagram (Fig. 5) could be interpreted as a mixing line between N-MORB magmas (or sources) and E-MORB magmas or alkaline magmas similar to Azores alkali basalts. Mixing relations are further explored in Figure 7. The mixing curve was calculated for mixing between Sample 556-8-2, 27-29 cm and the alkali basalt F33 from Faial Island, Azores Island (White et al., 1979). This particular Faial sample $(42.2 \mathrm{ppm} \mathrm{La}$, $4.2 \mathrm{ppm} \mathrm{Ta}$ ) has been chosen as being representative of relatively primitive $(\mathrm{Mg}$-number $>65)$, enriched mantle magmas. The $\mathrm{La}$ / Ta ratios of the N-MORBs $(\mathrm{La} / \mathrm{Ta}>$ 15 ) are very poorly correlated with La content, which is consistent with the tenet that $\mathrm{La} / \mathrm{Ta}$ and $\mathrm{La} / \mathrm{Hf}$ ratios are not systematically fractionated by moderate degrees of melting or crystallization. Figure 7 offers one explanation for the $\mathrm{La} / \mathrm{Ta}$ variations in the Leg $82 \mathrm{~N}-\mathrm{MORBs}$, i.e., mixing of N-MORB magmas with less than $2 \%$ of an enriched alkaline component. This small amount of mixing will have a minor effect on absolute LREE contents but will not significantly alter $\mathrm{La} / \mathrm{Yb}, \mathrm{La} / \mathrm{Ti}$, and $\mathrm{La} / \mathrm{Sm}$ ratios (Figs. 6, 8, 9). Actually, the E-MORB magmas also qualify as enriched end-members, but the re- 


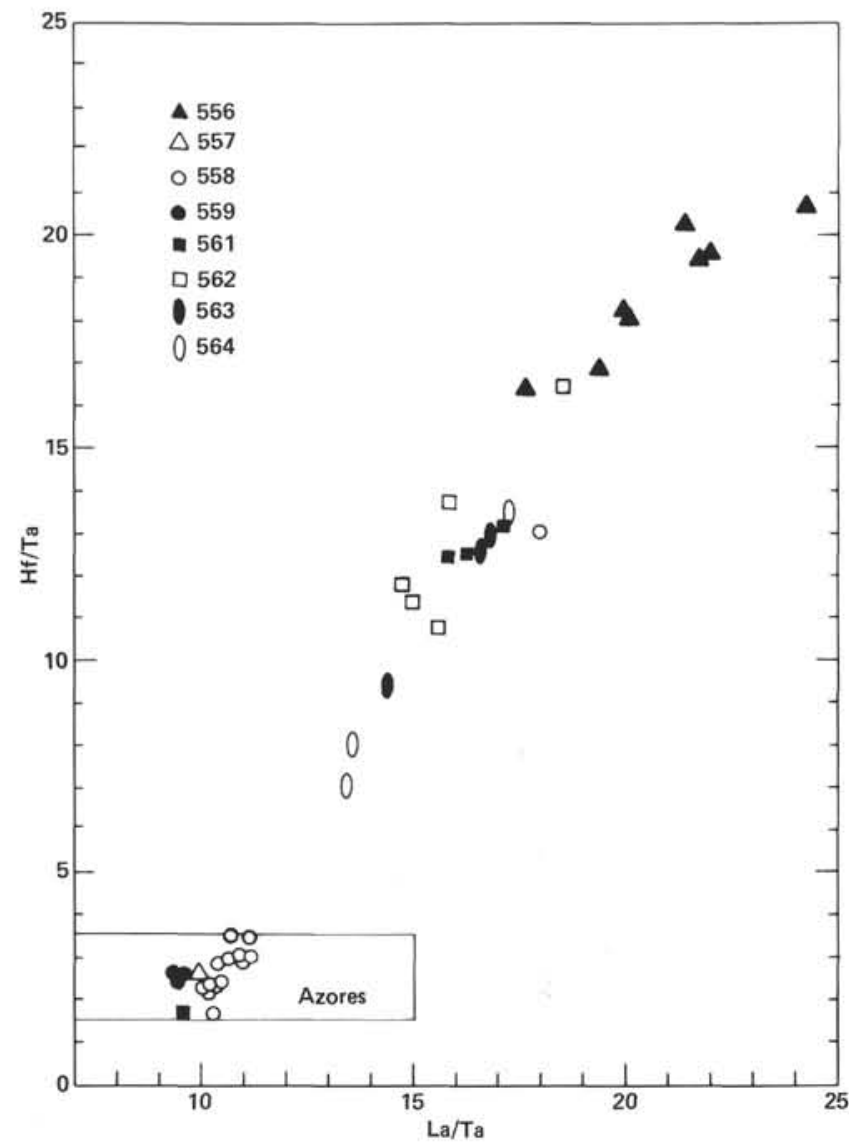

Figure $5 . \mathrm{Hf} / \mathrm{Ta}$ versus $\mathrm{La} / \mathrm{Ta}$ for Leg 82 basalts. The linear data array suggests that the variation is due to mixing involving an enriched alkaline end-member similar to Azores alkali basalt magmas (White et al., 1979). See Figure 7 for details of the mixing model.

quired amount of enriched component would then be five to ten times larger. The discussion in the next section will show that interpretation of the $\mathrm{La} / \mathrm{Ta}$ variations in terms of magma mixing is not unique. The variable $\mathrm{La} / \mathrm{Ta}$ ratios might equally well reflect source mixing (less than $0.1 \%$ enriched component) or local source heterogeneities that are too small to affect the ratios of other incompatible elements.

\section{Mixing Relations in the Leg 82 E-MORBs}

Two models have been proposed to explain the occurrence of E-MORBs along the Mid-Atlantic Ridge between 30 and $40^{\circ} \mathrm{N}$. The first one invokes binary mixing between "normal" depleted MORB (or their source regions) and Azores Mantle Plume magmas enriched in incompatible trace elements and radiogenic $\mathrm{Sr}, \mathrm{Nd}$, and $\mathrm{Pb}$ isotopes (Schilling, 1975; White and Schilling, 1978). The second model postulates the existence of regional chemical and isotopic heterogeneities in the subocean mantle, whose origins might be unrelated to the Azores volcanism (O'Nions et al., 1978; Wood et al., 1979; Davies, 1981). Because of its conceptual simplicity, the Azores Mantle Plume mixing hypothesis can be tested quite rigorously. To do so we will investigate whether or not the trace element variations in the E-MORBs are consistent with magma or source mixing and whether or not the Azores magma are plausible enriched end-members.

Before proceeding with the discussion of mixing relations, we would like to call attention to two chemical aspects of the Leg 82 E-MORBs. Firstly, the MgO (Fig. 4), $\mathrm{Cr}$ (Table 1), and Ni (Sachtleben et al,. this volume) contents are generally higher than in the Leg 82 N-MORBs. This precludes crystal fractionation being of any importance in establishing the trace element characteristics of the Leg 82 E-MORBs. (The fractionated basalts from Hole 557 are an exception). Secondly, there is no correlation between LREE enrichment and HREE abundance in the Leg 82 E-MORBs. Crossing REE patterns, as observed in the Hole 558 E-MORBs, are the hallmark of the "dynamic melting" model proposed by Langmuir et al. (1977) for basalts from the FAMOUS area. However, no indication for dynamic melting could be found in the REE systematics of the Leg 82 N-MORBs. Because there is no obvious reason why dynamic melting should be restricted to particular areas along a ridge, or to enriched sources for that matter, we cannot accept dynamic melting as the preferred model.

Two mixing models will be explored: (1) mixing between N-MORB magmas and alkaline magmas; and (2) mixing of depleted N-MORB mantle sources with alkaline magmas. For the sake of clarity, the alkali basalt F33 from Faial Island, Azores, (White et al., 1979) has been chosen to represent alkaline magmas for both models.

We will first consider the mixing relations in the chondrite-normalized $\mathrm{La} / \mathrm{Yb}$ versus $\mathrm{La} / \mathrm{Sm}$ diagram (Fig. 6). With the exception of the basalts from Holes 557 and 561 , the Leg 82 E-MORBs fit reasonably well to the mixing curve between N-MORB magmas and the alkali basalt F33. The magma mixing model predicts 8 to $40 \%$ alkaline component for the Hole 558 E-MORBs, 13 to $14 \%$ for the Hole 559 E-MORBs, and less than $3 \%$ for the transitional MORBs from Holes 562, 563, and 564 . If we consider the magma mixing curve, crystal fractionation after magma mixing does not appear to be a plausible explanation for the deviation of the E-MORBs from Holes 557 and 561, because crystallization of moderate amounts of olivine, plagioclase, and clinopyroxene does not significantly change the $\mathrm{La} / \mathrm{Sm}$ and $\mathrm{La} / \mathrm{Yb}$ ratios. So, if the REE geochemistry of these samples is due to mixing, the enriched end-members must have been different. The alignment of the Leg 82 E-MORBs along a mixing line can also be explained in terms of source mixing. The heavy arrows in Figure 6 indicate the calculated $\mathrm{La} / \mathrm{Sm}$ and $\mathrm{La} / \mathrm{Yb}$ ratios of magmas generated by $20 \%$ partial melting of N-MORB sources "contaminated" with $1.5,3$, and 5\% F33 alkaline component. The following assumptions were made for Sm: a concentration of $0.32 \mathrm{ppm}(1.5 \times$ chondrites $)$ in the $\mathrm{N}-\mathrm{MORB}$ source and partition coefficients of 0.001 , 0.01 , and 0.15 for olivine, orthopyroxene, and clinopyroxene. The other input parameters of the melting model were the same as used in the preceding section for modeling the $\mathrm{La} / \mathrm{Yb}$ variation in the N-MORBs. Results of this source mixing/partial melting model will be discussed more in detail in subsequent paragraphs. 


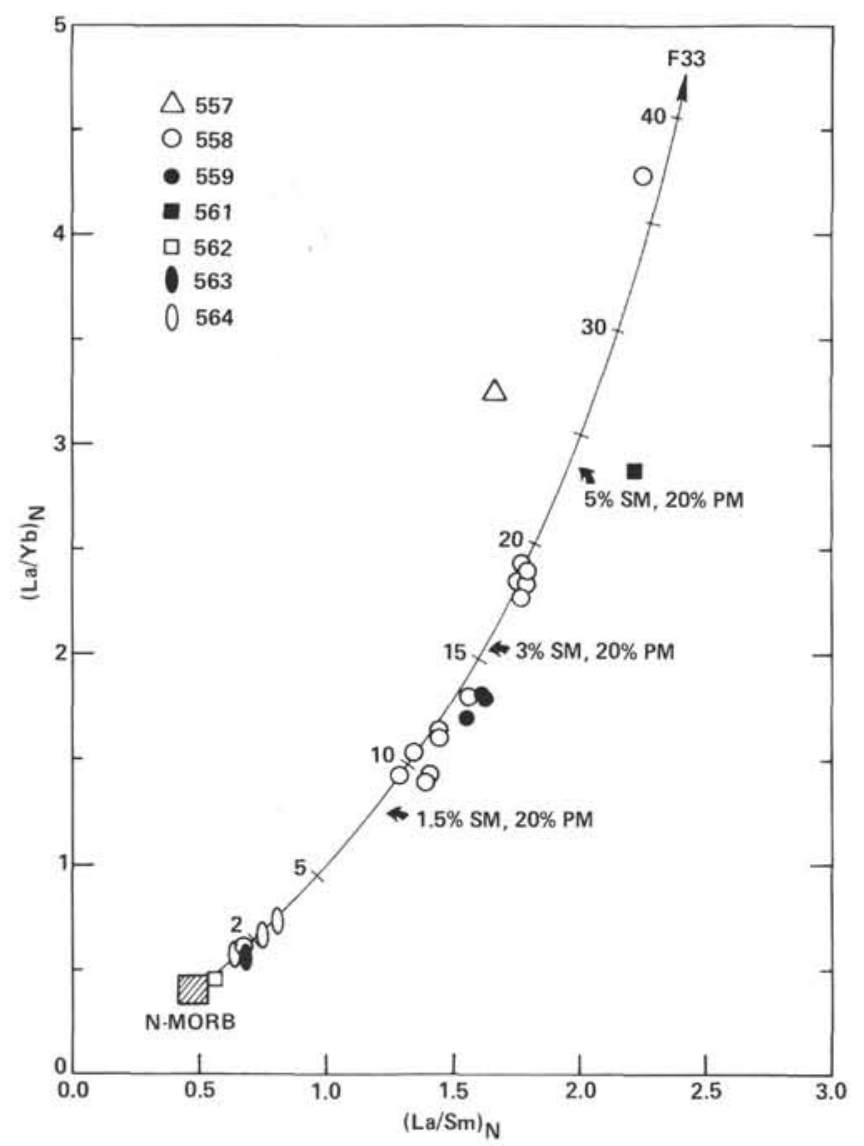

Figure 6. $\mathrm{La} / \mathrm{Yb}$ versus $\mathrm{La} / \mathrm{Sm}$ for Leg 82 basalts; both ratios are normalized to chondrites. The N-MORBs fall within a very narrow field (hatched square). The position of the E-MORBs (except for Holes 557 and 561) is consistent with either magma or source mixing. The mixing curve is calculated for magma mixing between Sample 556-8-2, 27-29 cm and alkali basalt F33 from Faial Island, Azores (White et al., 1979); numbers along the mixing curve refer to percentage of F33 component. The three heavy arrows indicate the calculated position of magmas derived by $20 \%$ partial melting (PM) of N-MORB sources mixed with $1.5,3$, and $5 \%$ of F33 component.

Plots involving ratios of incompatible and slightly compatible elements, such as Figures 5 and 6, do not distinguish between magma or source mixing for the Leg 82 E-MORBs. It might, therefore, be instructive to consider mixing plots involving absolute concentrations, such as Figures 7-9.

The percentages of magma mixing indicated by the La versus $\mathrm{La} / \mathrm{Ta}$ plot (Fig. 7) are not inconsistent with the amounts predicted by Figure 6, if allowance is made for minor variations in the composition of the depleted and enriched end-members and for changes in the $\mathrm{La}$ contents by moderate degrees of crystal fractionation after magma mixing. However, when the E-MORBs from the FAMOUS area (Bougault et al., 1979) and Hole 332B (Bougault, 1980) are considered, it appears that the chemistry of the E-MORBs has been controlled by source mixing rather than magma mixing. Indeed, the majority of the Hole 332B and FAMOUS MORBs plot well off magma mixing curves between common N-MORB and alkaline magmas. The near-vertical array of the Hole

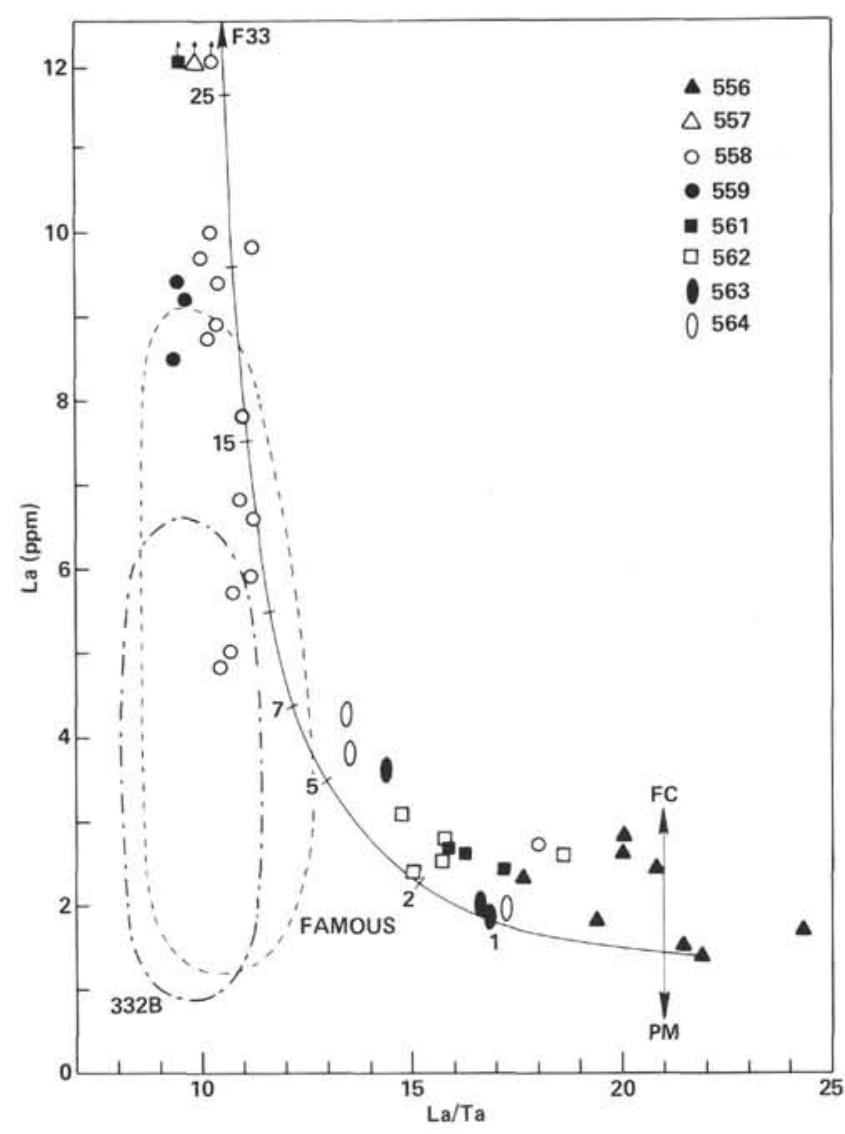

Figure 7. La versus $\mathrm{La} / \mathrm{Ta}$ for Leg 82 basalts. As the $\mathrm{La} / \mathrm{Ta}$ ratio is not changed by fractional crystallization (FC) or partial melting (PM), the variation of the $\mathrm{La} / \mathrm{Ta}$ ratio must be ascribed to mixing or source heterogeneity. End-members of the mixing curve are the same as in Figure 6. The moderately enriched MORBs from Hole 332B (Bougault, 1980) and the FAMOUS area (Bougault et al., 1979) fall well off magma mixing curves between Azores alkaline magmas and N-MORBs. This suggests that the trace element chemistry of the E-MORBs is controlled by source mixing rather than by magma mixing.

332B, FAMOUS, and Leg 82 E-MORBs in Figure 7 is more readily explained by different degrees of partial melting of N-MORB sources contaminated with $\geq 1.5 \%$ alkaline magma.

To further explore mixing relations, magma mixing curves have been superimposed on the $\mathrm{Yb}$ versus $\mathrm{La} / \mathrm{Yb}$ and $\mathrm{TiO}_{2}$ versus La plots (Figs. 8 and 9). It is immediately apparent that the REE systematics and $\mathrm{La} / \mathrm{Ti}$ variation of the Leg 82 E-MORBs are not consistent with magma mixing involving a unique depleted end-member. The whole array of N-MORB magmas must be considered as depleted end-members, and the magma mixing curves shown in Figures 8 and 9 are examples from a whole family of mixing curves converging towards the composition of basalt F33. Here again, source mixing offers an explanation that is at least as viable. The dashed, near-vertical lines in Figures 8 and 9 are batch partial melting paths calculated for depleted N-MORB sources contaminated with $1.5 \%$ (line A) and 3\% (line B) F33 alkaline component. The numbers along the melting curves refer to the percentage of batch melting. (The melt- 


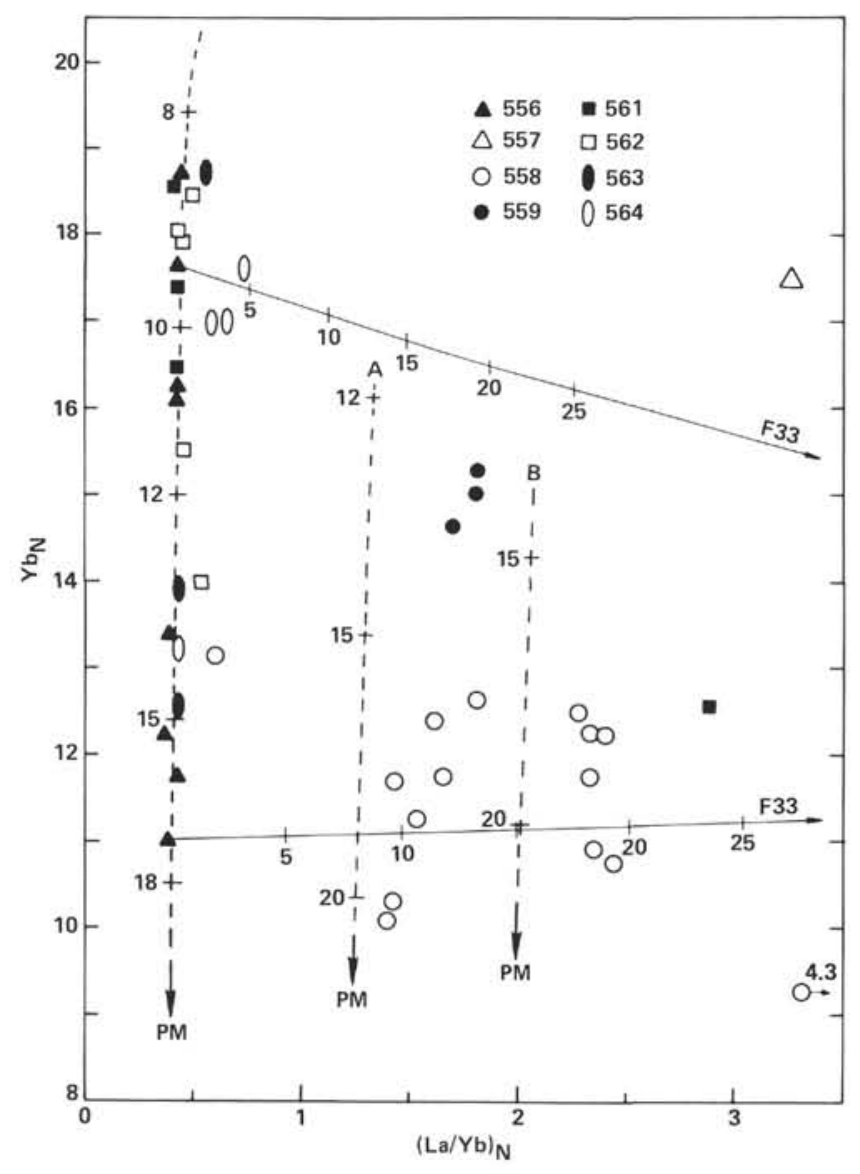

Figure 8. $\mathrm{Yb}$ versus $\mathrm{La} / \mathrm{Yb}$ ratio normalized to chondrites for $\mathrm{Leg} 82$ basalts. The twofold variation of rare earth element (REE) content in the Leg $82 \mathrm{~N}-\mathrm{MORBs}(\mathrm{La} / \mathrm{Yb} \leq 0.5)$ is primarily due to different degrees ( 8 to $18 \%$ ) of partial melting (PM). The dashed curve passing through the N-MORBs is a calculated batch partial melting path; see text for input parameters of the melting model. The REE systematics of the Leg 82 E-MORBs can be interpreted in terms of magma or source mixing. The full lines are two examples from a whole family of magma mixing curves between N-MORB magmas and Azores alkali basalt F33; numbers along mixing curves refer to percentage of F33 component. The dashed lines marked $\mathrm{A}$ and $\mathrm{B}$ are calculated partial melting paths for N-MORB mantle sources mixed with $1.5 \%$ (line A) and 3\% (line B) F33 magma; numbers refer to percentage of partial melting.

ing paths from Figure 9 are based on the reasonable assumptions that the $\mathrm{La} / \mathrm{Ti}$ ratio of the N-MORB source was identical to the $\mathrm{La} / \mathrm{Ti}$ ratio of the N-MORBs and that Ti behaved as an incompatible element after exhaustion of clinopyroxene from the mantle sources.) Our analysis of the data shows that the geochemistry of the transitional and enriched Leg 82 MORBs is consistent with $\geq 0.5$ to $5 \%$ admixture of alkaline component.

Whereas the trace element characteristics of the Leg $82 \mathrm{E}-\mathrm{MORBs}$ can be used to promote both the magma and source mixing models, there is some evidence to definitely favor the source mixing model:

1. The Nd isotopic data are not easily reconciled with magma mixing, even if allowance is made for variability in the isotopic and trace element composition of the end-members (Jenner et al., this volume).

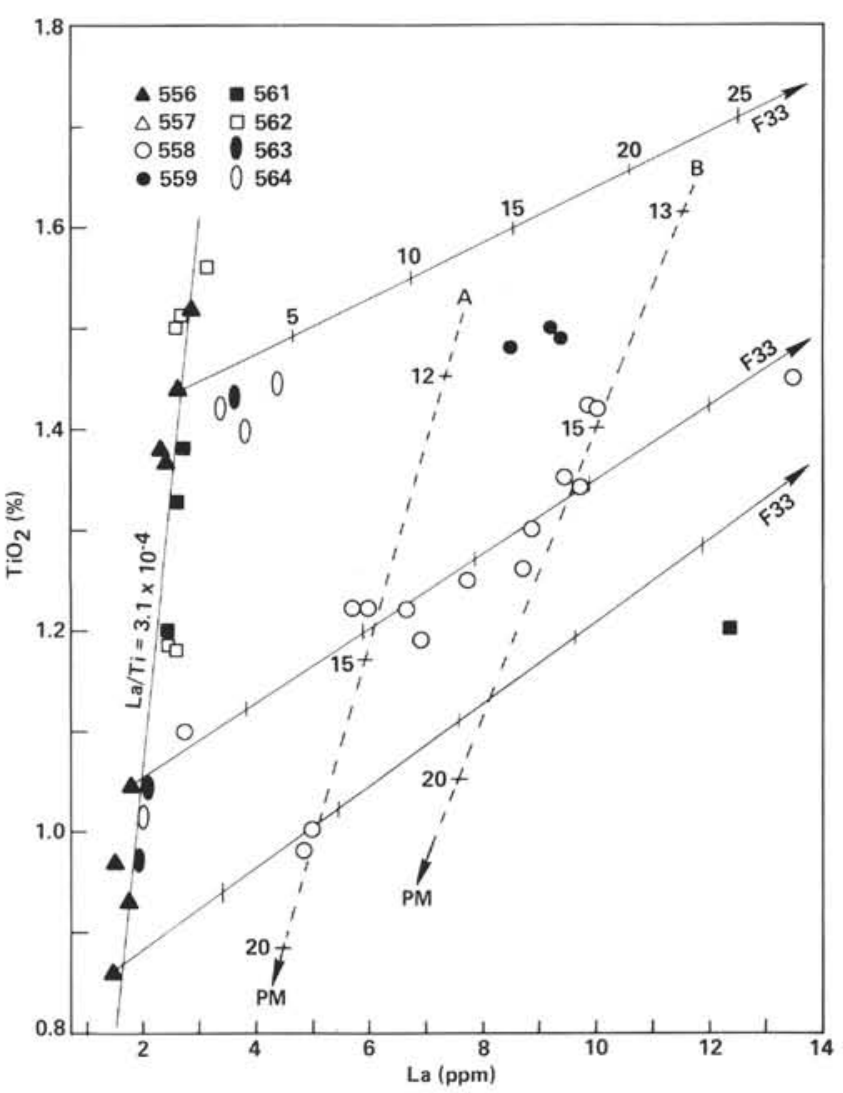

Figure 9. $\mathrm{TiO}_{2}$ versus $\mathrm{La}$ for Leg 82 basalts. Note the constant $\mathrm{La} / \mathrm{Ti}$ ratio of the N-MORBs. The full lines marked F33 are magma mixing curves, the dashed lines marked $\mathrm{A}$ and $\mathrm{B}$ are partial melting paths; see Figure 8 caption for further explanations.

2. Magma mixing does not appear to be a viable model for the moderately enriched FAMOUS and Hole 332B MORBs (Fig. 7), and there is no obvious reason to invoke special circumstances for either the Leg 82 or the FAMOUS and Hole 332B basalts.

3. The LREE-depleted basalt from Hole 558 (Sample 558-28-3, 118-120 cm) might provide an important clue. Its ${ }^{143} \mathrm{Nd} /{ }^{144} \mathrm{Nd}$ ratio is within the range of $\mathrm{E}$ MORBs (Jenner et al., this volume), although source or magma mixing calculations point to a much smaller admixture of enriched component. This sample apparently derives from an enriched source that lost a small fraction of melt before the main melting event. In contrast, it is not so easy to imagine a simple process that can deplete a melt in incompatible trace elements.

We are still left with the question of whether the source mixing process is directly related to the Azores Mantle Plume magmatism. The Azores magmas indeed appear to be suitable enriched end-members, but any alkaline or nephelinitic melt generated in the subocean mantle is probably quite similar to the Azores magmas with respect to trace element geochemistry. It seems reasonable to attribute the occurrence of E-MORBs in Hole 557 to Azores plume input, but the correlation of light REE enrichment with distance from the Azores Triple Junction is tenuous at best for the other Leg 82 holes. This 
observation favors alternative models, such as episodic source mixing with "fracture zone-derived" enriched magmas (Flower, 1981).

Finally, there is the problem of recent mixing versus long-lived mantle heterogeneities (O'Nions et al., 1978; Wood et al., 1979; Davies, 1981). Although trace element concentrations do not provide information on the timing of the enrichment event, the data for the Leg 82 basalts may indirectly have a bearing on this question. Indeed, N-MORBs with amazingly constant $\mathrm{La}$ / Sm (Fig. 6), La/Yb (Fig. 8), and La/Ti (Fig. 9) ratios have been derived from a large, homogeneous mantle source over a distance of $1200 \mathrm{~km}$ along the Mid-Atlantic Ridge during a period of approximately $20 \mathrm{Ma}$ (37-15 Ma). These data seem to be at variance with the recent emphasis on small-scale mantle heterogeneity in the area under study.

\section{CONCLUSIONS}

The almost twofold variation of absolute concentrations of incompatible trace elements in the Leg 82 $\mathrm{N}-\mathrm{MORBs}$ is primarily due to different degrees ( 8 to $18 \%$ ) of batch partial melting. The Leg 82 N-MORBs have $\mathrm{MgO}$ and $\mathrm{Ni}$ contents that are too low to qualify the MORBs as primary mantle melts; they most likely evolved from a sequence of more primitive magmas by 5 to $15 \%$ olivine fractionation before eruption. The remarkably constant $\mathrm{La} / \mathrm{Yb}, \mathrm{La} / \mathrm{Sm}$, and $\mathrm{La} / \mathrm{Ti}$ ratios of the Leg 82 N-MORBs apparently require a large, homogeneous mantle source underneath a segment $(1200 \mathrm{~km}$ long) of the Mid-Atlantic Ridge.

The variation of highly to moderately incompatible elements (REE, HF, Ta, Ti) in the Leg 82 E-MORBs is consistent with magma or source mixing between $\mathrm{N}$ MORB magmas or sources and an enriched component similar to Azores alkali basalts. However, the combined trace element and $\mathrm{Nd}$ isotopic data (Jenner et al., this volume) strongly favor source mixing ( $\geq 0.5$ to $5 \%$ enriched component). The association of depleted MORBs with transitional and enriched MORBs in Holes 561, 563 , and 564 underscores the episodic and localized nature of mixing processes.

The absence of a regular spatial distribution of Leg $82 \mathrm{E}-\mathrm{MORBs}$ as a function of distance from the Azores Triple Junction casts serious doubts on the validity of Azores Mantle Plume mixing models advocated by Schilling (1975) and White and Schilling (1978). The enriched alkaline magmas involved in the source mixing are probably not directly related to the Azores magmatism.

\section{ACKNOWLEDGMENTS}

This paper has greatly benefited from constructive reviews by J. W. Delano and A. J. Irving. We thank G. Van Den Eynde for technical assistance with the analyses. This work was supported in part by the Belgian Inter-University Institute for Nuclear Sciences (I.I.K.W.) and the Deutsche Forschungsgemeinschaft (Grants Schm 250-28, 29).

\section{REFERENCES}

Bender, J. F., Hodges, F. N., and Bence, A. E., 1978. Petrogenesis of basalts from the project FAMOUS area: experimental study from 0 to 15 kbars. Earth Planet. Sci. Lett., 41:277-302.

Bougault, H., 1980. Contribution des éléments de transition à la genèse des basaltes océaniques [Ph.D. dissert.]. Université de Paris VII, Paris.

Bougault, H., Cambon, P., Corré, O., Joron, J. L., and Treuil, M., 1979. Evidence for variability of magmatic processes and upper mantle heterogeneity in the axial region of the Mid-Atlantic Ridge near $22^{\circ}$ and $36^{\circ} \mathrm{N}$. Tectonophysics, $55: 11-34$.

Clague, D. A., Frey, F. A., Thompson, G., and Rindge, S., 1981. Minor and trace element geochemistry of volcanic rocks dredged from the Galapagos Spreading Centre: role of crystal fractionation and mantle heterogeneity. J. Geophys. Res., 86:9469-9482.

Davies, G. F., 1981. The earth's neodymium budget and structure and evolution of the mantle. Nature, 290:208-213.

Flower, M. F. J., 1981. Binary mixing in ocean-ridge spreading segments. Nature, 292:45-47.

Frey, F. A., Dickey, J. S., Thompson, G., Bryan, W. B., and Davies, H. L., 1980. Evidence for heterogeneous primary MORB and mantle sources, NW Indian Ocean. Contrib. Mineral. Petrol., 74: 387-402.

Fujii, T., and Bougault, H., 1983. Melting relations of a magnesian abyssal tholeiite and the origin of MORBs. Earth Planet. Sci. Lett., 62:283-295

Hertogen, J., and Gijbels, R., 1971. Instrumental neutron activation analysis of rocks with a Low-Energy Photon Detector. Anal. Chim. Acta, 56:61-82.

Langmuir, C. H., Bender, J. F., Bence, A. E., Hanson, G. N., and Taylor, S. R., 1977. Petrogenesis of basalts from the FAMOUS area: Mid-Atlantic Ridge. Earth Planet. Sci. Lett., 36:133-156.

Langmuir, C. H., Vocke, R. D., Hanson, G. N., and Hart, S. R., 1978. A general mixing equation with applications to Icelandic basalts. Earth Planet. Sci. Lett., 37:380-392.

O'Hara, M. J., 1977. Geochemical evolution during fractional crystallisation of a periodically refilled magma chamber. Nature, 266: 503-507.

O'Nions, R. K., Evensen, N. M., Hamilton, P. J., and Carter, S. R., 1978. Melting of the mantle past and present: isotope and trace element evidence. Phil. Trans. R. Soc. London, Ser. A, 258:547-559.

Rhodes, J. M., and Dungan, M. A., 1979. The evolution of ocean floor basalts. In Talwani, M., Harrison, C. G., and Hayes, D. E. (Eds.), Deep drilling results in the Atlantic Ocean: ocean crust: Washington (Am. Geophys. Union), Maurice Ewing Series, 2: 262-272.

Schilling, J.-G., 1975. Azores mantle blob: rare earth evidence. Earth Planet. Sci. Lett., 25:103-115.

Stolper, E., and Walker, D., 1980. Melt density and the average composition of basalt. Contrib. Mineral. Petrol., 74:7-12.

White, W. M., and Schilling, J.-G., 1978. The nature and origin of geochemical variation in Mid-Atlantic Ridge basalts from the Central North Atlantic. Geochim. Cosmochim. Acta, 42:1501-1516.

White, W. M., Tapia, M. D. M., and Schilling, J.-G., 1979. The petrology and geochemistry of the Azores Islands. Contrib. Mineral. Petrol., 69:201-213.

Wood, D. A., 1979. A variably veined suboceanic upper mantle-genetic significance for mid-ocean ridge basalts from geochemical evidence. Geology, 7:499-503.

Wood, D. A., Tarney, J., Varet, J., Saunders, A. D., Bougault, H., Joron, J. L., Treuil, M., and Cann, J. R., 1979. Geochemistry of basalts drilled in the North Atlantic by IPOD Leg 49: implications for mantle heterogeneity. Earth Planet. Sci. Lett., 42:77-97.

Date of Initial Receipt: 22 June 1983

Date of Acceptance: 31 January 1984 